\title{
Sobre a (homo)sexualidade nos meios de comunicação (1980-2010)
}

About (homo)sexuality in the media (1980-2010)

Sobre la (homo)sexualidad en los medios de comunicación (1980-2010)

\author{
Alexandre Sebastião Ferrari Soares ${ }^{1, a}$ \\ asferraris@globo.com | http://orcid.org/o00o-0003-0922-2905 \\ ${ }^{1}$ Universidade Estadual do Oeste do Paraná, Centro de Educação, Comunicação e Artes. Cascavel, PR, Brasil. \\ a Doutorado em Letras pela Universidade Federal Fluminense.
}

\section{Resumo}

Nesta nota de conjuntura, proponho mostrar um percurso da relação entre a homossexualidade e a imprensa de circulação nacional, aqui no Brasil. Como ponto de partida, abordo a emergência da Aids, no início dos anos de 1980, tendo em vista que para falar sobre a homossexualidade, os meios de comunicação recorriam aos discursos médico e religioso para discursivizar o homossexual/homossexualidade e finalizo nos anos 2010, quando, nestes mesmos veículos de informação, surgem outras relações para os sujeitos LGBTQI+. A partir da teoria francesa de análise do discurso, escrevo sobre o funcionamento da imprensa e os deslizamentos de sentidos nesses últimos anos de uma relação que nunca acaba: esses sujeitos sempre são objetos de consideração no discurso jornalístico.

Palavras-chave: Discurso jornalísticos; Percurso discursivo; Teoria francesa de análise do discurso; Sexualidade; Aids. 


\begin{abstract}
In this note on current situation, I propose to demonstrate a path of the relation between homosexuality and the press of national circulation in Brazil. As a starting point, I speak of the emergence of AIDS in the early 1980s, given that in order to talk about homosexuality the media resorted to medical and religious discourses to enunciate about the homosexual/the homosexuality, and I finish in the 2010s, when, in the same information carriers, other relations arise for LGBTQI+ subjects. From the French theoretical approach of discourse analysis, I write about the operations of the press and the slip of meanings in recent years of a relationship that never ends: these subjects are always objects of consideration in journalistic discourse.
\end{abstract}

Keywords: Journalistic discourse; Discursive path; French discourse analysis theory; Sexuality; AIDS.

\title{
Resumen
}

En esta nota de coyuntura, propongo mostrar un recorrido de la relación entre la homosexualidad y la prensa de circulación nacional, aquí en Brasil. Como punto de partida, hablo de la emergencia del sida, a principios de los años 1980, teniendo en cuenta que, para hablar sobre la homosexualidad, los medios de comunicación recurrían a los discursos médico y religioso para discursivizar el homosexual/la homosexualidad, y termino en los años 2010, cuando en estos mismos vehículos de información surgen otras relaciones para los sujetos LGBTQI+. A partir de la teoría francesa de análisis del discurso, escribo sobre el funcionamiento de la prensa y los deslizamientos de sentidos en estos últimos años de una relación que nunca termina: esos sujetos siempre son objetos de consideración en el discurso periodístico.

Palabras clave: Discurso periodístico; Recorrido discursivo; Teoría francesa de análisis del discurso, Sexualidad; Sida.

Este texto compõe o dossiê $\mathbf{4 0}$ anos do movimento LGBT no Brasil: comunicação, saúde e direitos humanos.

Contribuição dos autores: o autor é responsável por todo o texto.

Declaração de conflito de interesses: não há.

Fontes de financiamento: não houve.

Considerações éticas: não há.

Agradecimentos/Contribuições adicionais: não há.

Histórico do artigo: submetido: 17 jun 2018 | aceito: 21 jun 2019 | publicado: 28 jun. 2019.

Apresentação anterior: não houve.

Licença CC BY-NC atribuição não comercial. Com essa licença é permitido acessar, baixar (download), copiar, imprimir, compartilhar, reutilizar e distribuir os artigos, desde que para uso não comercial e com a citação da fonte, conferindo os devidos créditos de autoria e menção à Reciis. Nesses casos, nenhuma permissão é necessária por parte dos autores ou dos editores. 
Para um analista de discurso que se filia à teoria francesa de análise do discurso, a língua não é apenas um instrumento de comunicação como pensado por Jakobson ${ }^{1}$, ou seja, a partir dos elementos básicos da comunicação (emissor, receptor, referente, mensagem, canal, código) a compreensão se dá como um passe de mágica: como se a língua fosse transparente e os sentidos colados no significante.

Para um analista filiado à escola francesa, deve-se levar em conta alguma coisa do exterior da língua para compreender o que nela é dito. A descrição da sua estrutura não é suficiente para explicar seu funcionamento: é fundamental para a compreensão desse funcionamento entender que a língua, o discurso e a ideologia trabalham simultaneamente. Não há um exterior à língua, como pensado por Saussure², a língua (estrutura) se opondo à fala (o uso). Há, nessa posição teórica, uma estrutura que só funciona porque é atravessada por suas condições de produção, pela posição ocupada pelo sujeito e por suas filiações.

A memória dos sentidos de um discurso e suas condições de produção não é um acessório, mas indispensável à própria significação. O discurso é efeito de sentido entre interlocutores. Deslocamos ‘função' (estrutura) para o ‘funcionamento' (a relação da língua com o ‘Acontecimento Discursivo') e assim deslocamentos também o secundário para o constitutivo.

Isso fica mais claro quando pensamos, por exemplo, no uso de palavras tais como ‘homossexualismo' e 'homossexualidade'. Alguns poderiam pensar que se trata apenas de sinonímia, um termo por outro e um único sentido. Para um analista, ao se deparar com uma ou outra dessas palavras, depara-se também com filiações discursivas distintas: sentidos e sujeitos se constroem ao mesmo tempo. Ao significar, o sujeito também se significa. Ele diz de si, do lugar que ocupa diante daquilo a que ele se refere.

A memória discursiva diz respeito à recorrência de dizeres que emergem a partir de condições de produção específicas (possibilidade de que alguma coisa aconteça), mantendo-se, sendo atualizada ou esquecida de acordo com o processo discursivo. A memória é algo que fala sempre, antes, em outro lugar.

Ela não tem relação com as 'lembranças pessoais', porque é concebida numa esfera social. Pêcheux ${ }^{3}$ nos diz que a "memória deve ser entendida aqui não no sentido diretamente psicologista da 'memória individual', mas no encontro da memória mítica, da memória social inscrita em práticas, e da memória construída do historiador” (p. 44; destaque no original).

São as redes de memória que possibilitam a retomada de "já-ditos"3, atualizando-os à historicidade do Acontecimento Discursivo, ou seja, do encontro de uma memória com uma atualidade que desloca a memória ${ }^{4}$ (p.17).

Se tratamos das condições de produção de um discurso como fundamental para a compreensão do que ali se diz, não se pode perder de vista o lugar que os meios de comunicação ocupam no imaginário dos sujeitos. A partir dos mitos de "verdade, imparcialidade, neutralidade e objetividade" ${ }^{5}$ os meios de comunicação vão produzindo memórias. Essas memórias (do passado e do futuro) vão estabilizando sentidos e imobilizando relações sobre aquilo que se diz.

Esse discurso, pautado nos mitos construídos em torno dele, vai construindo a história da homossexualidade/do homossexual e (re)produzindo os sentidos (passados, presentes e futuros) a respeito dos seus referentes: "Trata-se de uma prática discursiva que atua na construção e reprodução de sentidos, 'prática essa realizada a partir de um efeito ilusório da função do jornal como responsável apenas por uma transmissão objetiva de informações'. O discurso jornalístico constrói-se, dessa forma, 'com base em um pretenso domínio da referencialidade, pois baseia-se em uma concepção de linguagem que considera a língua como instrumento de comunicação de informações"”6 (p.34).

Essa pretensa informatividade se sustenta em um funcionamento prêt-à-porter da informação, ou seja, os jornais disponibilizam aos leitores as notícias que estão ali ao alcance das nossas mãos (de qualquer um de nós) prontas para serem consumidas. Elas ocupam 'sempre-já' as páginas impressas pré-significadas por uma relevância constituída pela relação imaginária entre jornais e leitores: "se o jornal publicou é porque é importante ou só é importante o que aparece no jornal”'. Para o leitor fica apagado esse funcionamento 
jornalístico de existir uma seleção das notícias (não se tem acesso a tudo, mas à pauta decidida pelos editores), é igualmente apagado que as manchetes também são resultados dessa decisão. No imaginário (constituído historicamente entre jornais e leitores) é como se os fatos falassem por si.

De acordo com Mariani', "Leitores e jornalistas ficam imersos em uma agenda (organizada pelos 'donos' do jornal) previamente constituída por interpretações já tomadas como consensuais, ou que virão a se tornar consenso por força, exatamente, dos efeitos produzidos pela própria imprensa" (p.34).

Na década de 1980, aqui no Brasil, os meios de comunicação (mais especificamente as revistas 'Veja', 'Isto é' e 'Superinteressante'i) de uma forma quase que geral, construíram uma relação causal entre ser homossexual e ser portador do vírus HIV ${ }^{\text {ii }}$, mesmo quando o discurso da medicina já era outro, na metade dessa década, ou seja, não se falava mais em 'grupo de risco' mas em 'comportamento de risco'. Ainda que a homossexualidade, em 1980, não fosse mais considerada uma doença pela Associação Psiquiátrica Americana e no Brasil, no início de 1985, o Conselho Federal de Medicina tenha passado a homossexualidade para o Código 206.9, sob a denominação "outras circunstâncias psicossociais" - juntamente com o desemprego e o desajuste social, os meios de comunicação continuaram a produzir, como natural, aquela relação, conforme destaco das manchetes citadas por Fausto Neto ${ }^{9}$ (p.50-51; grifos meus):

'A peste rosa' 'Jornal da Tarde' de 01.09 de 1983;

'Doença misteriosa alastra-se nos USA' 'O Globo' de 09.02 de 1983;

'AIDS - a peste do século XX - doença chega ao Brasil e alarma comunidade gay' 'Correio Braziliense' de 17.06 de 1983;

'Mal de homossexuais ataca os britânicos' 'O Globo' de 19.05 de 1983;

'Homossexuais cubanos transmitem a doença' 'O Globo' de 19.03 de 1983;

'Síndrome ou Câncer-gay' 'A Tarde’ de 07.06 de 1983;

'Síndrome gay deixa Europa amedrontada' 'Correio Braziliense' de 06.07 de 1983;

'Síndrome gay leva os americanos à histeria' 'Correio Braziliense' de 09.07 de 1983.

É possível ler nessas manchetes de jornais de grande circulação aqui no Brasil, da primeira metade da década de 1980, o que se dizia sobre ser gay e ser portador em potencial do vírus HIV: as palavras têm história e só funcionam porque se inscrevem em redes discursivas. Elas vão construindo sítios de significância ${ }^{10}$ e sedimentando sentidos como naturais. Não é à toa que a peste é 'rosa', que a doença chega ao Brasil e 'alarma' a comunidade gay (nada se diz do vírus fora dessa comunidade), que é um 'mal dos homossexuais'. Esses sentidos circulavam como verdade porque partiam, em sua maioria, do discurso da ciência posto em circulação pelo discurso jornalístico.

Esse discurso tem como característica atuar na institucionalização de sentidos, o que significa dizer que ele contribui para a constituição do imaginário social e para a cristalização da memória do passado, bem como para a construção da memória do futuro7. Nos anos 1980, para se falar sobre a homossexualidade, falava-se necessariamente ou sobre doença ou sobre pecado. E sobre o merecimento de estar doente em virtude de 'seus comportamentos que iam de encontro com a natureza'. As editorias de onde partiam tais sentidos eram preferencialmente 'Ciência e Saúde'. E tudo isso produzia cristalização de sentidos sobre os sujeitos homossexuais, seus estilos de vida e suas relações sexuais.

Essa memória sobre a homossexualidade não é apagada mesmo depois de tantos deslocamentos científicos e sociais. Ela continua produzindo seus efeitos quando um deputado propõe um projeto de cura gay, quando profissionais solicitam ao Conselho de Psicologia poder tratar da homossexualidade

i Essas revistas compuseram o corpus de análise de uma pesquisa finalizada em 2006 sobre os meios de comunicação e a relação entre ser gay e portador do vírus HIV e lançada em livro em $2019^{7}$.

ii O furo se encontrava nas cartas de leitores comentando as matérias produzidas pelas revistas ${ }^{7}$. 
como se fosse uma doença, quando dizem que a homossexualidade é uma opção, quando uma autoridade afirma preferir ter um filho ladrão a um filho homossexual, quando outra afirma que uma surra evitaria a homossexualidade da criança. Esses sentidos continuam produzindo fiações, continuam reverberando nos meios de comunicação.

No entanto, há muita diferença entre a década de 1980 e a primeira década do século XXI, nos meios de comunicação: um deslocamento significativo nos sentidos que circulam sobre os sujeitos LGBTTTQQIAA+iii. Lá, apenas os sujeitos gays masculinos eram discursivizados e não tinham espaços para dizerem sobre si. Era falados pela medicina, pela religião e pela justiça. Quando falavam, reproduziam os sentidos que eram ditos sobre eles.

Na primeira década do século XXI, a homossexualidade não é apenas masculina como na década de 1980. Há espaço para a travesti longe das páginas policiais, para o sujeito trans, para a lésbica. Fala-se sobre preconceito, sobre adoção, sobre o casamento, sobre o amor. Nesses mesmos meios de comunicação ${ }^{11}$, os espaços reservados para se falar sobre sexualidade migraram de 'Ciência/Saúde' para 'Comportamento, Gente, Sociedade, Brasil'. E esses deslocamentos são significativos porque colocam a sexualidade $\backslash$ o sujeito em um outro lugar discursivo, criando em torno deles outros sítios de significância.

Não quero com isso dizer que aqueles velhos sentidos também não circulem. Circulam e são postos imediatamente em xeque por uma voz de autoridade. Há sempre alguém pronto para responder e produzir outros sentidos sobre aquilo que se diz. Quando se fala sobre doença, sobre anormalidade, sobre casamento ser apenas entre um homem e uma mulher, rebate-se imediatamente a sociedade heteronormativa, questiona-se a não relação entre sexo (biológico) e identidade, fala-se sobre as diferentes formas de amor, sobre diversidade, sobre a laicidade do Estado, sobre a ciência em detrimento do senso comum.

Há colunas nos jornais ('O Globo', 'Folha de S.Paulo', 'Estadão', entre outros) que tratam exclusivamente de assuntos de interesses da comunidade LGBTTTQQIAA+: estilo de vida, programação cultural, festas, sexualidade produzindo um deslocamento bastante significativo porque a abordagem não passa pelo crivo do fundamentalismo religioso, da doença, do crime.

Há uma memória que nunca esquece, mas há também resistência a ela, e dessa forma os sujeitos LGBTTTQQIAA+ podem falar sem necessariamente confirmar o discurso médico que o tratava como doente ou o discurso religioso que o tratava como pecador. Outras palavras e expressões surgem: homolesbotransfobia, homocultura, homoerotismo, homoafetividade, homocausto, homoerotização, homoadoção, parceria civil, casamento entre pessoas do mesmo sexo, beijo gay, orgulho gay colocando esses sujeitos num outro lugar onde a relação causal se dá a partir de outros sentidos bem diferentes daqueles de décadas anteriores.

\section{Referências}

1. Jakobson R. Linguística e Comunicação. São Paulo: Cultrix; 2005.

2. Saussure F. Curso de Linguística Geral. São Paulo: Cultrix; 2006.

3. Pêcheux M. O papel da memória. In: Achard P, Davallon J, Durand JL, Pêcheux M, Orlandi EP, organizadores. O papel da memória. 3. ed. Campinas: Pontes; 2015. p. 49-57.

4. Pêcheux M. Discurso: estrutura ou acontecimento. Campinas: Pontes; 2002.

5. Mariani B. O PCB e a imprensa - os comunistas no imaginário dos jornais 1922-1989. Rio de Janeiro: Revan; 1998.

6. Mariani B. Sentidos de subjetividade: imprensa e psicanálise. Polifonia. 2006;12(1):21-45.

iii Lésbicas, gays, bissexuais, transgêneros, transexual, 2/Two-Spirit (Dois Espíritos), queer, questionando, intersex, assexual, aliado e quem mais aparecer. 
7. Soares ASF. A homossexualidade e a aids no imaginário de revistas semanais (1985-1990). São Carlos: Pedro \& João; 2019.

8. Trevisan JS. Devassos no paraíso: a homossexualidade no Brasil, da colônia à atualidade. Rio de Janeiro: Editora Record; 2000.

9. Fausto Neto A. Comunicação e mídia impressa: estudo sobre a AIDS. São Paulo: Hacker Editores; 1999.

10. Orlandi E. Interpretação: autoria, leitura e feitos do trabalho simbólico. Petrópolis: Vozes; 1996.

11. Soares ASF. Sobre a homossexualidade na mídia (2005-2010). In: Mariani B, Medeiros V, Dela-Silva S, organizadoras. Discurso, arquivo e... Rio de Janeiro: 7 Letras; 2011. p.1-10. 